\title{
Effect of diabetes mellitus during the luteal phase of the oestrous cycle on preovulatory follicular function, ovulation and gonadotrophins in gilts
}

\author{
N. M. $\operatorname{Cox}^{1}$, K. A. Meurer ${ }^{1}$, C. A. Carlton ${ }^{1}$, R. C. Tubbs ${ }^{2 *}$ and \\ D. P. Mannis ${ }^{2}$ \\ ${ }^{1}$ Department of Animal and Dairy Sciences, and ${ }^{2}$ College of Veterinary Medicine, Mississippi State \\ University, Mississippi State, MS 39762, USA
}

\begin{abstract}
Development of preovulatory follicles was studied during the oestrous cycle in two experiments designed to examine the effects of short-term lack of insulin on preovulatory follicular function and (Expt 2 only) ovulation. In Expt 1, on day 12 of the third postpubertal oestrous cycle, insulin treatment was discontinued in streptozocin-induced diabetic gilts $(n=4)$, and on day 18, ovaries were removed from the diabetic gilts and from four normal untreated gilts. Diabetic gilts had a higher percentage of macroscopically atretic follicles (29.4 versus $6.8 \%$; SEM $=5.9, P<0.03$ ) than did normal gilts. Binding of ${ }^{125}$ I-labelled hCG by freshly collected granulosa cells from non-atretic follicles was similar in diabetic and normal gilts. Diabetic gilts had more LH peaks in $3 \mathrm{~h}$ on days 12-17 of the oestrous cycle than did normal gilts $(2.3$ versus $1.6 ; \operatorname{SEM}=0.12 ; P<0.01)$. Serum oestradiol and progesterone concentrations were not affected by treatment, but serum testosterone was increased $(P<0.01)$ in diabetic gilts. In Expt 2, insulin treatment was withdrawn from nine diabetic gilts on day 12 of the oestrous cycle and ten normal gilts served as controls. On day 18, ovaries were removed from six diabetic and six normal gilts; four normal and three diabetic gilts were ovariectomized 25 days after oestrus. Follicular diameter of diabetic gilts tended to be smaller than that of control (control: 3.95 versus diabetic: $3.01 \mathrm{~mm}$; $\mathrm{SEM}=0.4$, $P<0.08$ ) and the proportion of follicles with histologic evidence of atresia was higher in diabetic gilts (control: 29 versus diabetic: $47 \%$; SEM $=5 ; P<0.05$ ) on day 18 . In both experiments, the insulin-like growth factor I (IGF-I) and oestradiol concentrations of follicular fluid of diabetic gilts untreated with insulin from day 12 to day 18 was lower than in nondiabetic gilts. After day 18 in Expt 2, normal gilts exhibited oestrus (duration of cycle was $20 \pm 0.5$ days) accompanied by preovulatory surges in oestradiol and LH, whereas diabetic gilts did not exhibit oestrus or ovulate. In diabetic gilts, oestradiol concentrations were lower compared with those of normal gilts, and LH patterns were characterized by two (two gilts) or three (one gilt) increases of more than $2 \mathrm{ng} \mathrm{ml}^{-1}$ between day 18 and day 25 . Thus, impaired follicular function in diabetic gilts is not explained by decreased function of the hypothalamo-pituitary axis, since LH was not decreased. We conclude that the decreased oestradiol production by diabetic gilts indicates either disrupted steroidogenesis due to the acute absence of insulin or lowered IGF-I, or both.
\end{abstract}

\section{Introduction}

In pigs, ovarian follicles enter ovulatory or degenerative pathways between day 14 and day 18 of the oestrous cycle (Clark et al., 1982; Foxcroft and Hunter, 1985). We reported that administration of insulin during this time increased ovulation rate (Cox et al., 1987) and decreased macroscopic signs

*Present address: Commercial Agriculture Program, W234 College of Veterinary Medicine, University of Missouri-Columbia, Columbia, Missouri 65211, USA.

Received 8 July 1993 of follicular atresia in cyclic pigs and in pigs treated with pregnant mares' serum gonadotrophin (PMSG) (Matamoros et al., 1990, 1991). Untreated diabetes in pigs, caused by withdrawal of insulin for 4 days of follicular growth induced by PMSG, increased atresia of small follicles but did not affect the number of presumed preovulatory follicles (Meurer et al., 1991). However, in that study, concentrations of oestradiol and insulin-like growth factor-I (IGF-I) were lower in large ( $\geqslant 7 \mathrm{~mm}$ diameter) follicles of diabetic gilts than in those of non-diabetic gilts, indicating abnormal hormone secretion despite similar numbers of follicles. Concentrations of IGF-I were also lower in Downloaded from Bioscientifica.com at 04/26/2023 07:12:02AM 
peripheral serum, but intrafollicular steroidal differences were not reflected in peripheral serum.

The inhibitory influences of diabetes on follicular function have been attributed to various portions of the hypothalamohypophyseal-ovarian axis, and all three parts of the axis may be affected under different conditions (Kirchick et al., 1978; Djursing et al., 1982; Katayama et al., 1984; Valdes et al., 1991). However, there is evidence that complex paracrine control, involving growth factors and metabolic hormones, could account for follicular development in the absence of changes in gonadotrophins (see for example, Tonetta and diZerega, 1989). Meurer et al. (1991) did not observe any negative effect of diabetes on circulating gonadotrophins in PMSG-treated gilts; in fact, in two gilts LH concentrations increased $72 \mathrm{~h}$ after PMSG. However, PMSG-induced follicular growth is known to be associated with low LH and FSH concentrations (Flowers et al., 1989). Furthermore, follicular growth induced by exogenous gonadotrophins exhibits distinct functional differences from that in cyclic gilts (Wiesak et al., 1990). The major objective of the present experiments was therefore to evaluate the effects of insulin withdrawal on preovulatory follicular growth (Expts 1 and 2), ovulation (Expt 2), and associated gonadotrophin concentrations (both Expts) in cyclic gilts. A secondary objective was to determine whether intrafollicular influences of diabetes on steroids and IGF-I were reflected in secretion of hormones into the ovarian venous circulation (Expt 1).

\section{Materials and Methods}

\section{Experiment 1}

Eight crossbred (Yorkshire $\times$ Duroc) gilts that had been unilaterally ovariectomized before puberty as part of a previous study (Meurer et al., 1991) were used during their third postpubertal oestrous cycle. Four gilts were non-diabetic ( $144 \pm 6 \mathrm{~kg}$ body mass at the time of this study) and four were streptozocin-induced diabetic ( $139 \pm 6 \mathrm{~kg}$ body mass). Briefly, diabetes was induced between 8 and 12 weeks of age, and gilts were maintained on continuous insulin therapy until the present experiment, except for a period of 4 days after the induction of follicular development with PMSG at $15 \mathrm{I} \pm 4$ days of age as part of the previous experiment (Meurer et al., 1991). Age at puberty was $182 \pm 3$ days for control gilts and $187 \pm 4$ days for diabetic gilts. Feed intake of normoglycaemic gilts during the entire period after induction of diabetes was limited to approximately $90 \%$ of maximum intake to keep body masses (determined weekly) similar to the diabetic animals, which were fed ad libitum as described by Meurer et al. (1991). During the experimental period, normal gilts remained on the feed intake calculated to maintain their masses similar to those of diabetic gilts. Insulin therapy maintained plasma glucose at similar concentrations to that of non-diabetic animals, between 80 and $100 \mathrm{mg}$ per $100 \mathrm{ml}$, during the pre-experimental period as previously described, and the existence of diabetes was confirmed by a glucose challenge test before death (Meurer et al., 1991).

All pigs were catheterized before $13: 00 \mathrm{~h}$ on day 11 of the third oestrous cycle (first day of oestrus = day 1) with a polyethylene catheter placed nonsurgically and aseptically into the anterior vena cava. Day 12 was the first day without insulin therapy. Blood samples were obtained every $12 \mathrm{~h}$ from $18: 00 \mathrm{~h}$ on day 11 to $06: 00 \mathrm{~h}$ on day 18 of the oestrous cycle and for a $3 \mathrm{~h}$ period on each of days 12-17 for analysis of LH pulses (samples every $15 \mathrm{~min}$ between 10:00 and 13:00 h).

On day 18, ovaries were removed from each gilt under anaesthesia induced with sodium pentothal (Biotal, $3 \mathrm{mg} \mathrm{kg}^{-1}$ i.v.; Boehringer-Ingelheim Animal Health, Inc., St Joseph, MO) and maintained with methoxyflurane (Pitman-Moore Inc., Washington Crossing, NJ) and nitrous oxide. A blood sample from an ovarian vein was obtained approximately $I \mathrm{~cm}$ from the ovary immediately before removal of the ovary on day 18 . Immediately after removal of the ovary, the diameters of all visible follicles were measured to the nearest millimetre and follicles were assigned to a size class (small: $<3 \mathrm{~mm}$; medium: 3-6 mm or large: $\geqslant 7 \mathrm{~mm}$ ). Macroscopic signs of atresia were noted following the procedures of Moor et al. (1978) and Matamoros et al. (1990). Fluid was aspirated from individual non-atretic follicles and diluted in $0.01 \mathrm{~mol} \mathrm{PBS} \mathrm{I}^{-1}$ containing $0.1 \%$ gelatin at $\mathrm{pH} 7.5$ to dilutions ranging from $1: 10$ to $1: 40$, depending on the volume of follicular fluid available and the amount needed for radioimmunoassays. Macroscopically atretic follicles were excluded because fluid viscosity prevented reliable collection. The diluted follicular fluid was then frozen until assays were performed. Granulosa cells from up to four (if available) macroscopically non-atretic follicles from each size class, for a total of 73 follicles, were collected and assayed immediately for hCG binding according to the procedures of Matamoros et al. (1990). A total of 185 follicles was analysed for oestradiol, progesterone, testosterone and IGF-I.

\section{Experiment 2}

Ten contemporary non-diabetic and nine streptozocininduced diabetic crossbred (Yorkshire $\times$ Duroc) gilts were used. Diabetes was induced at $118 \pm 4.3$ days of age and gilts were maintained on exogenous insulin treatment as in Expt 1. The later age was chosen, on the basis of observations in Expt 1 that puberty age, ovulation rate and cycle duration were not affected by diabetes mellitus, and the different periods of diabetes mellitus with insulin treatment were not expected to affect the results. Puberty onset in Expt 2 was at $185 \pm 4.6$ and $184 \pm 4.9$ days of age for normal and diabetic gilts, respectively. On day 12 of the second or third oestrous cycle (two normal and two diabetic gilts were on the third), insulin treatment was withdrawn from diabetic gilts. Ovaries were removed from six normal and six diabetic gilts on day 18 as in Expt 1 . For the remaining gilts, i.v. catheters were inserted on day 18 as described for Expt $I$ and blood samples were collected three times a day. Ovaries were removed and collection of blood samples was stopped 25 days after oestrus (designated this way because no diabetic gilts exhibited oestrus). Gilts were weighed on day 11, 17 and before surgery on day 18.

After the ovaries were removed, the size of all follicles was measured. One ovary had the follicular fluid removed for assay, as in Expt 1, and the second ovary was processed for histological assessment of atresia. For histology studies, the Downloaded from Bioscientifica.com at 04/26/2023 07:12:02AM 
ovaries were placed in Bouin's fixative for $36 \mathrm{~h}$, then prepared in paraffin wax sections $(5 \mu \mathrm{m})$ and stained with haematoxylin and eosin (Carson et al., 1979). An atretic follicle was defined as one containing at least $10 \%$ pyknotic granulosa ; cells (five sections of 100 cells examined per follicle). The percentage of atretic follicles was based on observations of all follicles $\geqslant 3 \mathrm{~mm}$ diameter. Follicular development on day 18 was less advanced than it was in Expt 1; follicle size classes were therefore expressed as $<3,4-6$ and $>6 \mathrm{~mm}$. Ninety-seven follicles were analysed for follicular fluid hormones and 73 for histologic evidence of atresia.

\section{Assays}

Follicular fluid was used at the initial dilutions described above for IGF-I, diluted to final concentrations of 1:100 or 1:200 in PBS for progesterone and testosterone and to 1:1000 for oestradiol radioimmunoassays, on the basis of preliminary determinations of dilution rates. Sample volumes assayed for steroids were as follows: $200 \mu \mathrm{l}$ for dilutions from mediumsized and large-sized follicles and $400 \mu \mathrm{l}$ or $600 \mu \mathrm{l}$ for dilutions of small-sized follicles. Ovarian venous samples were diluted 1:200 for steroid radioimmunoassays. Over the dilutions used, validity of assays was not affected.

Serum $\mathrm{LH}$ concentrations were determined by a doubleantibody radioimmunoassay using a rabbit anti-porcine $\mathrm{LH}$ serum (No. 566; provided by G. D. Niswender, Colorado State University, Fort Collins, CO) and porcine standard (LER 786-3; provided by L. E. Reichert, Albany Medical College, Albany, NY) validated previously (Niswender et al., 1970; Cox et al., 1987). Intra- and interassay coefficients of variation were 8.9 and $8.3 \%$, respectively. Sensitivity of the assay was $0.12 \mathrm{ng} \mathrm{ml}^{-1}$.

Serum FSH was assayed by validated procedures (Expt 1 only) using USDA-FSH-ppI as standard and USDA 1010-10 as antibody (both provided by D. G. Bolt, National Hormone and Pituitary Program, Beltsville, MD; USDA: Cox et al., 1987). Intra- and interassay coefficients of variation were $6.4 \%$ and $11.2 \%$, respectively. Sensitivity of the assay was $0.3 \mathrm{ng} \mathrm{ml}^{-1}$.

Concentrations of IGF-I in peripheral serum, follicular fluid, and ovarian venous serum were assayed according to validated procedures (Houseknecht et al., 1988; Matamoros et al., 1991) with the exception that $48 \mathrm{~h}$ after adding the tracer hormone, $100 \mu \mathrm{l}$ of $4 \%$ normal rabbit serum in assay buffer and $200 \mu \mathrm{l}$ of second antibody (1:10 in assay buffer) were added, followed by $1.0 \mathrm{ml}$ ice-cold $6 \%$ polyethylene glycol (P2139, Sigma Chemical Co., St Louis, MO) in distilled water to aid in precipitation of antibody-bound hormone. Intra- and interassay coefficients of variation were 3.4 and $4.0 \%$, respectively, and sensitivity of the assay was $1.9 \mathrm{ng} \mathrm{ml}^{-1}$.

Concentrations of oestradiol in peripheral serum, follicular fluid, and ovarian venous serum were assayed by procedures validated in our laboratory for serum (Cox et al., 1988) and follicular fluid (Matamoros et al., 1990). Intra- and interassay coefficients of variation were 7.2 and $11.5 \%$, respectively. Sensitivity of the assay was $1.6 \mathrm{pg} \mathrm{m}^{-1}$. Efficiencies of a single extraction in ethyl acetate were $95 \%$ in follicular fluid and $87 \%$ in serum, and values were corrected accordingly.
Concentrations of testosterone (Expt 1 only) in peripheral serum, follicular fluid and ovarian venous serum were assayed by procedures validated in our laboratory (Matamoros et al., 1990), with the exception that ${ }^{125}$ I-labelled testosterone (testosterone-3(O-carboxymethyl) oximino-(2- $\left[{ }^{125} I\right]$ iodohistamine) (Amersham Corporation, Arlington Heights, IL) was used as the radioactive tracer. A single extraction with $\left[{ }^{3} \mathrm{H}\right]$ testosterone yielded efficiencies of $77 \%$ for follicular fluid and $85 \%$ for serum, and samples were corrected for extraction efficiency. Intra- and interassay coefficients of variation were 12 and $22 \%$, respectively. Sensitivity of the assay was $20 \mathrm{pg} \mathrm{ml}^{-1}$.

Progesterone in peripheral serum, follicular fluid, and ovarian venous serum (Expt 1 only) was assayed by procedures validated in our laboratory (Rainey et al., 1990) and modified for ${ }^{125}$-labelled progesterone (Meurer et al., 1991). Intra- and interassay coefficients of variation were 11.7 and $9.5 \%$, respectively. Sensitivity of the assay was $0.03 \mathrm{ng} \mathrm{ml}^{-1}$. A single extraction yielded recoveries of $72 \%$ for follicular fluid and $82 \%$ for serum, and samples were corrected for extraction efficiency.

Binding of hCG by freshly collected granulosa cells was assessed in Expt 1 as described by Matamoros et al. (1990). Plasma glucose concentrations were measured by the glucose oxidase-peroxidase method (Cox et al., 1987) and serum non-esterified fatty acids (Expt 1) as described previously (Matamoros et al., 1991).

\section{Statistical analyses}

Proportions of follicles in individual size classes were expressed as the percentages of total follicles present, such that there was a single observation for each animal. Proportions and numbers of follicles were analysed using one-way analysis of variance (Steel and Torrie, 1980) with treatment as the independent variable. For steroid concentrations and ratios in follicular fluid, models included effects of treatment, pig within treatment (error term used to test effect of treatment), follicle size class ( $\leqslant 3 \mathrm{~mm}, 3-6 \mathrm{~mm}$ and $\geqslant 7 \mathrm{~mm}$ ) and the interaction of size class and treatment. For circulating hormone concentrations, the model used included effects of treatment, pig within treatment (error term used to test effect of treatment), time and the time by treatment interaction. Where main effects and interactions were significant, means were separated by the method of least significant difference (SAS, 1988).

The methods of Goodman and Karsch (1980) were used to identify LH pulses. Variables obtained using these criteria were analysed for effects due to treatment using one-way analysis of variance (SAS, 1988).

\section{Results}

\section{Experiment 1}

During the period when diabetic gilts were without insulin, changes in mass of diabetic $(-2.3 \pm 1.5 \mathrm{~kg})$ and normoglycaemic gilts ( $-1.5 \pm 1.5 \mathrm{~kg}$ ) were similar. On day 18 , the numbers of corpora lutea were similar for non-diabetic and diabetic gilts (13.0 and 14.5 , respectively; $\mathrm{SEM}=1.5$ ).

Downloaded from Bioscientifica.com at 04/26/2023 07:12:02AM 
Table 1. Numbers of follicles and percentages of total follicles in each follicle class in non-diabetic control and diabetic gilts according to follicular size and macroscopic atresia (Expt 1)

\begin{tabular}{|c|c|c|c|c|c|c|}
\hline \multirow{2}{*}{$\begin{array}{l}\text { Class of } \\
\text { follicle }\end{array}$} & \multicolumn{2}{|c|}{ Number of follicles } & \multirow[b]{2}{*}{$\mathrm{SEM}^{\mathrm{a}}$} & \multicolumn{2}{|c|}{ Percentage of total } & \multirow[b]{2}{*}{ SEM } \\
\hline & Control & Diabetic & & Control & Diabetic & \\
\hline$<3 \mathrm{~mm}$ & 11.8 & 21.3 & 9.2 & 18.2 & 26.0 & 6.9 \\
\hline $3-6 \mathrm{~mm}$ & 37.5 & 23.0 & 9.4 & 59.5 & 36.2 & 10.7 \\
\hline$\geq 7 \mathrm{~mm}$ & 5.8 & 3.8 & 3.0 & 15.5 & 8.4 & 8.1 \\
\hline All $\geq 3 \mathrm{~mm}$ & 43.3 & 26.8 & 7.1 & $75.0^{\mathrm{b}}$ & $44.6^{\mathrm{c}}$ & 9.2 \\
\hline Atretic & $4.3^{\mathrm{b}}$ & $18.3^{c}$ & 3.9 & $6.8^{\mathrm{b}}$ & $29.4^{\mathrm{c}}$ & 5.9 \\
\hline Total & 59.4 & 66.4 & 14.0 & & & \\
\hline
\end{tabular}

${ }^{a}$ Values are least squares means and SEMs are pooled estimates of variance.

b.c Within a row, variable means with different superscripts are significantly different $(P<0.05)$.

Table 2. Intrafollicular hormones from each follicle size class in non-diabetic control and diabetic gilts (Expt 1)

\begin{tabular}{|c|c|c|c|c|c|}
\hline $\begin{array}{l}\text { Size of } \\
\text { follicle }\end{array}$ & State & $\begin{array}{l}\text { Oestradiol }^{\mathrm{a}} \\
\left(\mathrm{ng} \mathrm{ml}{ }^{-1} \text { ) }\right.\end{array}$ & $\begin{array}{l}\text { Progesterone } \\
\quad\left(\mathrm{ng} \mathrm{ml}^{-1}\right)\end{array}$ & $\begin{array}{c}\text { Testosterone } \\
\left(\mathrm{ng} \mathrm{ml} \mathrm{ml}^{-1}\right)\end{array}$ & $\begin{array}{c}\text { IGF-I } \\
\left(\mathrm{ng} \mathrm{ml}^{-1}\right)\end{array}$ \\
\hline$<3 \mathrm{~mm}$ & $\begin{array}{l}\text { Normal } \\
\text { Diabetic }\end{array}$ & $\begin{array}{l}7 \pm 9 \\
7 \pm 6\end{array}$ & $\begin{array}{l}176 \pm 86 \\
111 \pm 73\end{array}$ & $\begin{array}{r}37 \pm 13 \\
8 \pm 11\end{array}$ & $\begin{array}{r}117 \pm 15^{b} \\
68 \pm 11^{c}\end{array}$ \\
\hline $3-6 \mathrm{~mm}$ & $\begin{array}{l}\text { Normal } \\
\text { Diabetic }\end{array}$ & $\begin{array}{l}19 \pm 3 \\
17 \pm 5\end{array}$ & $\begin{array}{l}188 \pm 21 \\
166 \pm 31\end{array}$ & $\begin{array}{l}20 \pm 4 \\
12 \pm 5\end{array}$ & $\begin{array}{r}115 \pm 5^{b} \\
63 \pm 8^{c}\end{array}$ \\
\hline$\geq 7 \mathrm{~mm}$ & $\begin{array}{l}\text { Normal } \\
\text { Diabetic }\end{array}$ & $\begin{array}{l}95 \pm 6^{b} \\
31 \pm 6^{c}\end{array}$ & $\begin{array}{l}185 \pm 38^{b} \\
475 \pm 39^{c}\end{array}$ & $\begin{array}{l}32 \pm 6 \\
22 \pm 7\end{array}$ & $\begin{array}{r}142 \pm 9^{b} \\
76 \pm 10^{c}\end{array}$ \\
\hline
\end{tabular}

${ }^{a}$ Values are least squares means and SEMs are pooled estimates of variance.

b.c Within a column and size class, values with different superscripts are significantly different $(P<0.0001)$.

The diabetic state was confirmed by significantly higher plasma glucose in diabetic than in non-diabetic gilts throughout the sampling period (treatment by time interaction, $P<0.0001)$. On the first day without insulin treatment, plasma glucose concentration averaged $293 \pm 9 \mathrm{mg}$ per $100 \mathrm{ml}$ in diabetic gilts. Over all sampling times, glucose averaged 447 and $83 \mathrm{mg}$ per $100 \mathrm{ml}$ in diabetic and non-diabetic gilts, respectively $(\mathrm{SEM}=25)$. Serum non-esterified fatty acids increased in diabetic gilts over the 7 day period (treatment by time interaction, $P<0.0003$ ), averaging $0.75 \mathrm{mEq} \mathrm{I}^{-1}$ and $0.11 \mathrm{mEq} \mathrm{I}^{-1}$ for diabetic and non-diabetic gilts, respectively $($ SEM $=0.17)$.

Diabetic gilts had similar numbers of macroscopically non-atretic follicles in each size class as did normal gilts, but a smaller percentage of total follicles present were $\geqslant 3 \mathrm{~mm}$ in diameter (Table 1). Diabetic gilts had higher numbers and percentages of atretic follicles than did control gilts. The highest incidence of atresia was in the small follicle size class and was greater for diabetic gilts (46 versus $10 \%$ of total small follicles; SEM $=7, P<0.009$, result not shown). Percentages of macroscopically atretic medium-sized follicles were 8 and $14 \%(S E M=5)$ for normal and diabetic gilts, respectively, and were similar. There were no large atretic follicles in normal gilts, and only one diabetic gilt had large atretic follicles $(n=2)$.
Granulosa cell hCG binding was not affected significantly by treatment, averaging 92 and $63 \mathrm{ng}$ per $10^{\circ}$ cells $(\mathrm{SEM}=31$ ) for all follicles of normal and diabetic gilts, respectively. Size class significantly $(P<0.05)$ affected binding of hCG: that of large follicles (153.9 $\pm 32.5 \mathrm{ng}$ per $10^{6}$ cells) exceeding that of medium-sized $\left(34.9 \pm 27.1 \mathrm{ng}\right.$ per $10^{\circ}$ cells) and small follicles (33.0 $\pm 35.9 \mathrm{ng}$ per $10^{6}$ cells).

In the two size categories of follicles $<7 \mathrm{~mm}$, the diabetic state did not alter intrafollicular concentrations of oestradiol, progesterone or testosterone. However, in follicles $\geqslant 7 \mathrm{~mm}$, diabetic gilts had significantly higher concentrations of progesterone and significantly lower concentrations of oestradiol than did controls. Diabetic gilts also had significantly lower concentrations of IGF-I in all sizes of follicles than did controls (Table 2).

Ratios of oestradiol to other steroids were lower in large follicles of diabetic compared with non-diabetic gilts (oestradiol:testosterone, $2.06 \pm 0.41$ versus $4.78 \pm 0.39$; and oestradiol:progesterone, $0.09 \pm 0.06$ versus $0.73 \pm 0.06 ; P<0.05$ ). For small and medium-sized follicles, ratios of oestradiol:testosterone were affected by diameter $(0.54 \pm 0.43$ for small and $1.33 \pm 0.26$ for medium-sized follicles; $P<0.05$ ), but not by treatment. Ratios of oestradiol:progesterone in small and medium-sized follicles averaged $0.14 \pm 0.05$ and were not affected by diameter or treatment.

Downloaded from Bioscientifica.com at 04/26/2023 07:12:02AM 


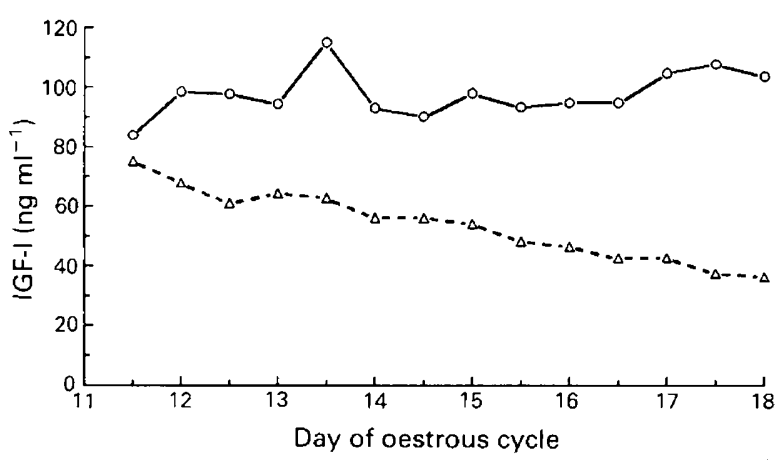

Fig. 1. Least squares means of serum immunoreactive insulin-like growth factor $(\mathrm{IGF}-\mathrm{I})(\mathrm{SEM}=6)$ in samples obtained every $12 \mathrm{~h}$ during days $11-18$ of the oestrous cycle for $(--\triangle--)$ diabetic and (-O-) normal gilts. A day by treatment interaction was observed $(P<0.0001)$ and diabetic gilts had lower IGF-I concentrations than did control gilts at all times except day 11.5.

Serum concentrations of IGF-I were similar for both treatments at the beginning of sampling but gradually declined in diabetic gilts after removal of insulin therapy (treatment by time interaction, $P<0.0001$; Fig. 1).

When samples taken at $12 \mathrm{~h}$ intervals only were considered, temporal patterns of $\mathrm{LH}$ and $\mathrm{FSH}$ were not influenced by treatment, although FSH decreased with day $(P<0.05$; Fig. 2). The low LH concentrations evident in all gilts at 06:00 h on day 12 of the oestrous cycle cannot be explained. Any stress associated with the catheterization procedure the day before would not be expected to cause decreased gonadotrophin secretion (Diekman et al., 1990). Interference owing to processing of blood samples was ruled out, as gilts reached day 12 of the cycle on different days. In addition, all blood samples from this period were not contiguous in the radioimmunoassay for $\mathrm{LH}$, and a repeat assay on these samples produced the same results.

Numbers of peaks of LH during $3 \mathrm{~h}$ sampling periods were greater for diabetic gilts $(2.3$ versus 1.6 peaks per $3 \mathrm{~h}$, SEM $=0.12, P<0.01$ ). The number of peaks also increased with day of the cycle $(P<0.01$; Fig. 3$)$. Mean LH peak amplitude (1.3 $\left.\pm 0.3 \mathrm{ng} \mathrm{ml}^{-1}\right)$, overall mean $\left(0.7 \pm 0.1 \mathrm{ng} \mathrm{ml}^{-1}\right)$, and mean baseline concentration $\left(0.4 \pm 0.1 \mathrm{ng} \mathrm{ml}^{-1}\right)$ were similar for diabetic and non-diabetic gilts.

There was no effect of treatment on concentrations of either progesterone or oestradiol in peripheral serum. Diabetic and normal gilts averaged 16.1 and $19.5 \mathrm{ng} \mathrm{ml}^{-1}$ (SEM = 5) for progesterone and 4.6 and $3.8 \mathrm{pg} \mathrm{ml}^{-1}$ (SEM = 1) for oestradiol, respectively. Serum testosterone increased after removal of insulin treatment (treatment by time interaction, $P<0.02$; Fig. 4). Over all sampling times, testosterone in serum of diabetic gilts averaged $0.07 \mathrm{ng} \mathrm{ml}^{-1}$ and in non-diabetic gilts $0.02 \mathrm{ng}$ $\mathrm{ml}^{-1}$ (SEM $\left.=0.01\right)$.

In ovarian vein serum on day 18 , concentrations of oestradiol $\left(0.20\right.$ and $0.10 \mathrm{ng} \mathrm{ml}^{-1}$; SEM $\left.=0.09\right)$, testosterone $(0.21$ and $\left.0.14 \mathrm{ng} \mathrm{ml}^{-1} ; \mathrm{SEM}=0.09\right)$ and progesterone $(22.5$ and $19.2 \mathrm{ng} \mathrm{ml}^{-1}$; $\mathrm{SEM}=5$ ) in non-diabetic and diabetic gilts, respectively, were similar. Diabetic gilts had lower IGF-I concentrations in ovarian vein serum than did normal gilts ( 36
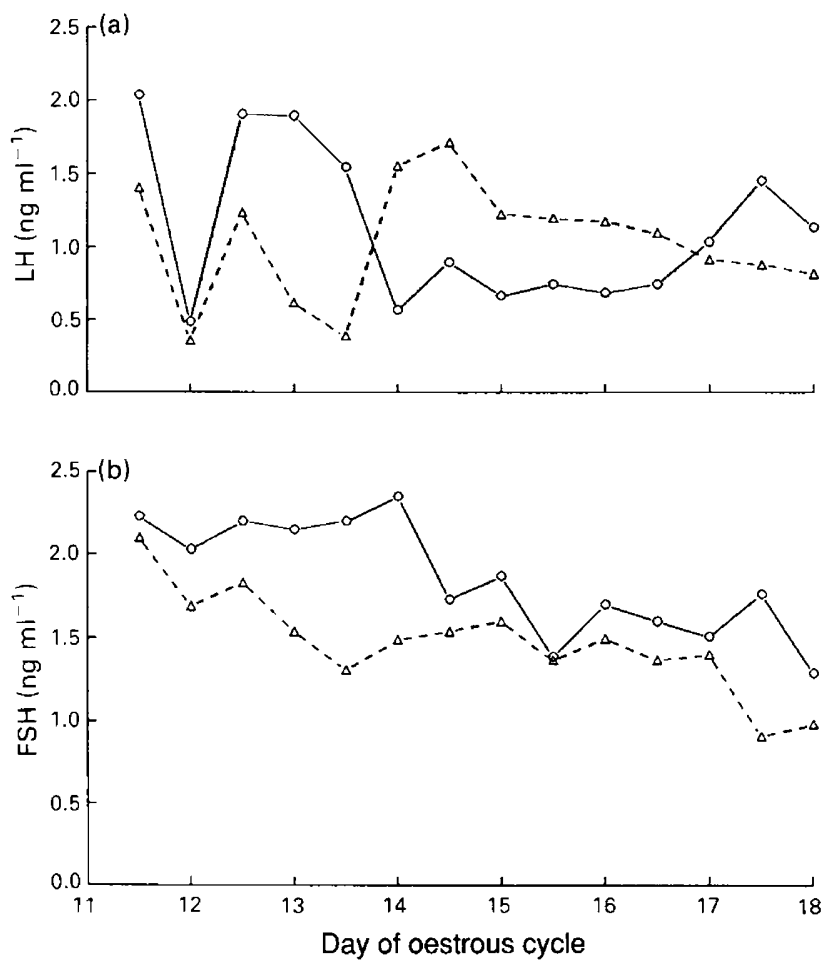

Fig. 2. Least squares means of serum immunoreactive (a) $\mathrm{LH}$ $($ SEM $=0.4)$ and $(b)$ FSH $($ SEM $=0.2)$ in samples obtained every $12 \mathrm{~h}$ during days $11-18$ of the oestrous cycle for $(--\triangle--)$ diabetic and $(-\mathrm{O}-$ ) normal gilts. There were no influences of treatment.

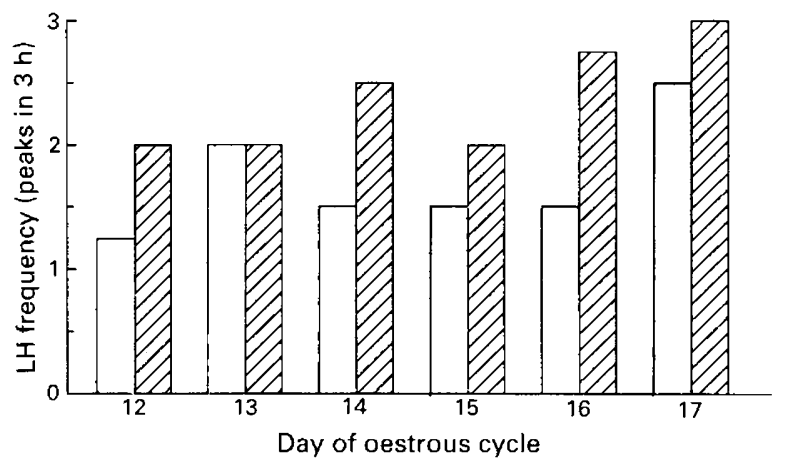

Fig. 3. Least squares means of numbers of $L H$ peaks $(S E M=0.2)$ during $3 \mathrm{~h}$ sampling on each of days $12-17$ of the oestrous cycle for $(\square)$ diabetic and $(\square)$ normal gilts. There were significant main effects of treatment $(P<0.01)$ and day of cycie $(P<0.01)$.

and $90 \mathrm{ng} \mathrm{ml}^{-1} ; \mathrm{SEM}=4 ; P<0.05$ ) on day 18 . Ovarian vein and peripheral concentrations of IGF-I were similar.

\section{Experiment 2}

On day 18 , diabetic gilts had higher blood glucose concentrations compared with normal animals, confirming the diabetic state $(472$ versus $73 \mathrm{mg}$ in $100 \mathrm{ml}$; SEM $=25 ; P<0.001$ ). From day 12 to day 18 , diabetic gilts lost body mass while 


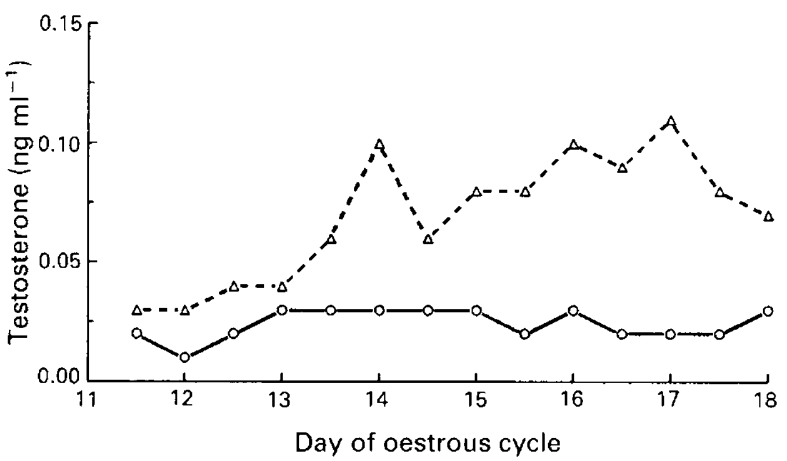

Fig. 4. Least squares means of serum testosterone $(\mathrm{SEM}=0.01)$ in samples obtained every $12 \mathrm{~h}$ during days $1 \mathrm{I}-18$ of the oestrous cycle for $(--\triangle--)$ diabetic and $(-\mathrm{O} \rightarrow$ ) normal gilts. Effects of treatment were significant $(P<0.05)$.

non-diabetic gilts maintained body mass $(-6.4$ versus $0.0 \mathrm{~kg}$; $\mathrm{SEM}=1.7 ; P<0.05$ ). For the seven animals sampled until day 25 , diabetic gilts lost body mass while non-diabetic gilts gained $(-7.7$ versus $3.4 \mathrm{~kg}$ from day 12 until $25 ; \mathrm{SEM}=2.0$; $P<0.001$ ). The numbers of corpora lutea on day 18 were similar for diabetic and normal gilts (15.1 and 15.6, respectively; $\mathrm{SEM}=2.0$ ).

Numbers of medium-sized follicles $(4-6 \mathrm{~mm})$ tended to be lower in diabetic than in normal animals, whereas small follicles $(<3 \mathrm{~mm})$ tended to be higher. The average diameter of follicles of normal gilts tended to exceed that of diabetic gilts (Table 3). Only two follicles from diabetic and four follicles from normal gilts were $>6 \mathrm{~mm}$; hormonal data are therefore presented for the smaller size classes only. The percentage of histologically atretic follicles was higher in diabetic than in non-diabetic gilts. Despite the moderate effects on follicular size distribution compared with Expt 1, diabetes significantly decreased follicular fluid concentrations of IGF-I and oestradiol (Table 4). Peripheral concentrations of immunoreactive IGF-I were lower $(P<0.05)$ in diabetic gilts, and they did not change at oestrus in non-diabetic gilts (Fig. 5).

Of the group of gilts that were given the opportunity to exhibit oestrus, all non-diabetic gilts and no diabetic gilts were observed in oestrus. Concentrations of LH on day 18 were similar for normal and diabetic gilts $\left(1.5 \pm 0.3 \mathrm{ng} \mathrm{ml}{ }^{-1}\right)$. However, normal gilts had preovulatory surges (peak magnitude $4.4 \pm 0.3 \mathrm{ng} \mathrm{ml}^{-1}$ ) that were preceded by sustained increases in oestradiol concomitant with behavioural oestrus (Fig. 6). The duration of the oestrous cycle for non-diabetic animals was $20 \pm 0.5$ days, and number of corpora lutea 5 days later was $16.3 \pm 0.5$. In contrast, diabetic gilts did not exhibit oestrus, did not ovulate and did not have a preovulatory oestradiol surge. On day 25 , no corpora lutea and no follicles greater than $2 \mathrm{~mm}$ diameter were visible in diabetic animals. However, diabetic gilts had two $(n=2$; Fig. $7 \mathrm{a}, \mathrm{c})$ or three ( $n=1$; Fig. $7 \mathrm{~b}$ ) sustained increases in $\mathrm{LH}$ which were smaller in peak magnitude $\left(2.9 \pm 0.3 \mathrm{ng} \mathrm{ml}^{-1} ; P<0.05\right)$ than preovulatory surges in non-diabetic gilts, but larger than LH concentrations on day $18(P<0.05)$. One diabetic gilt (Fig. $7 \mathrm{~b})$ had a brief increase in oestradiol on day 19 that was not sustained.

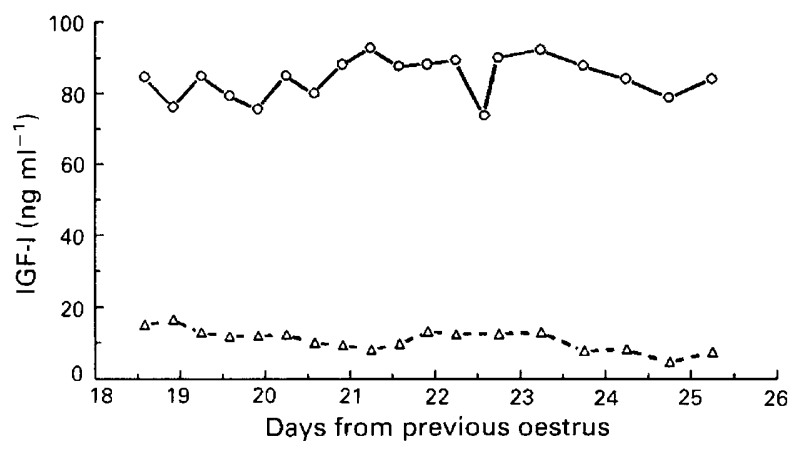

Fig. 5. Least squares means of serum immunoreactive insulin-like growth factor I (IGF-I) in samples obtained every $8 \mathrm{~h}$ during days 18-25 from the previous oestrus for $(--\triangle--)$ diabetic and $(-\mathrm{O}-)$ normal gilts. Effects of treatment were significant $(P<0.05)$. Insulin treatment was withdrawn from diabetic gilts from day 12. SEMs ranged from 5 to $10 \mathrm{ng} \mathrm{ml}^{-1}$ for non-diabetic animals and from 5 to $7 \mathrm{ng} \mathrm{ml}^{-1}$ for diabetic animals.

Peak oestradiol concentrations were 19 and $52 \mathrm{pg} \mathrm{ml}^{-1}$ $(\mathrm{SEM}=6 ; \quad P<0.01)$ for diabetic and non-diabetic gilts, respectively.

\section{Discussion}

Follicular development and the number of corpora lutea in Expt $I$ indicate that the single ovaries had undergone compensatory growth and that insulin-replacement treatment supported a normal ovulation rate in diabetic gilts. In both Expts, similarity in age at puberty and number of corpora lutea between diabetic and normal gilts indicates that insulin-replacement treatment before the experimental removal of insulin was sufficient for normal ovarian function. The adequacy of our insulinreplacement therapy has been confirmed in another study in which follicular size distribution, incidence of atresia, follicular hormone concentrations and ovulation rate were similar in non-diabetic gilts and in gilts receiving insulin treatment (Howell et al., 1992). Follicles collected on day 18 in normal and diabetic gilts were less developed in Expt 2 than in Expt $I$, but this difference is attributed to natural variation in follicular development rather than to any difference in experimental methods.

In Expt 1, acute onset of untreated diabetes decreased the proportion of follicles $\geqslant 3 \mathrm{~mm}$, which are presumed to contain the ovulatory population (Clark et al., 1982). Follicular development in Expt 2 appeared to be at a less advanced stage overall than in Expt 1, although atresia was increased comparably with Expt 1 . These results are consistent with earlier work in which the presence of insulin was negatively associated with follicular atresia (Matamoros et al., 1990, 1991; Meurer et al., 1991). In Expt 1, as well as in our previous study (Meurer et al., 1991), the greatest macroscopic atresia was in the population of small follicles, which undergo the most rapid atresia during preovulatory follicular growth (Dailey et al., 1975; Clark et al., 1982; Guthrie et al., 1990). Follicular size distribution was affected differently during the natural cycle than previously reported for PMSG-induced follicular growth (Meurer et al., 1991). In that study, only proportions of small Downloaded from Bioscientifica.com at 04/26/2023 07:12:02AM 
Table 3. Number of follicles, diameter and histologic assessment of atresia for non-diabetic control and diabetic gilts (Expt 2)

\begin{tabular}{|c|c|c|c|c|}
\hline \multirow[b]{2}{*}{ Follicles } & \multicolumn{2}{|c|}{ Treatment } & \multirow[b]{2}{*}{$\operatorname{SEM}^{\mathrm{a}}$} & \multirow[b]{2}{*}{$P$} \\
\hline & Normal & Diabetic & & \\
\hline Number $\leq 3 \mathrm{~mm}$ & 35.0 & 50.8 & 12.0 & 0.10 \\
\hline Number $4-6 \mathrm{~mm}$ & 32.3 & 21.6 & 5.0 & 0.10 \\
\hline Number $>6 \mathrm{~mm}$ & 2.2 & 0.3 & 1.1 & 0.26 \\
\hline Diameter (mm) & 3.95 & 3.01 & 0.4 & 0.08 \\
\hline Percentage atretic & 29.0 & 47.0 & 5.0 & 0.03 \\
\hline
\end{tabular}

${ }^{a}$ Values are least squares means and SEMs are pooled estimates of variance.

Table 4. Intrafollicular concentrations of immunoreactive insulin-like growth factor-I (IGF-I) and oestradiol on day 18 for non-diabetic control and diabetic gilts (Expt 2)

\begin{tabular}{|c|c|c|c|}
\hline \multirow{2}{*}{$\begin{array}{l}\text { Hormone } \\
\left(\mathrm{ng} \mathrm{ml} \mathbf{~}^{-1} \text { ) }\right.\end{array}$} & \multirow[b]{2}{*}{ Diameter of follicle } & \multicolumn{2}{|c|}{ Treatment } \\
\hline & & Normal & Diabetic \\
\hline IGF-I ${ }^{a, b}$ & $\begin{array}{l}\leq 3 \mathrm{~mm} \\
4-6 \mathrm{~mm}\end{array}$ & $\begin{array}{l}145 \pm 16 \\
153 \pm 9^{b}\end{array}$ & $\begin{array}{l}71 \pm 23 \\
80 \pm 12\end{array}$ \\
\hline Oestradiol $^{\mathrm{C}}$ & $\begin{array}{l}\leq 3 \mathrm{~mm} \\
4-6 \mathrm{~mm}\end{array}$ & $\begin{array}{l}51 \pm 11 \\
79 \pm 7\end{array}$ & $\begin{array}{l}17 \pm 15 \\
23 \pm 8\end{array}$ \\
\hline
\end{tabular}

${ }^{a}$ Values are least squares means and SEMs are pooled estimates of variance.

${ }^{b}$ Effect of treatment $(P<0.05)$; ${ }^{c}$ effect of treatment $(P<0.05)$ and diameter $(P<0.05)$.

$(<3 \mathrm{~mm})$ follicles were significantly affected by diabetes. In both studies, there were no negative influences of diabetes on gonadotrophin concentrations. However, differences in gonadotrophic stimuli to follicles (endogenous versus exogenous) may explain why different size populations of follicles were inhibited by diabetes during natural and PMSG-induced follicular growth. Wiesak et al. (1990) demonstrated differences in follicular size distribution and increased variation of follicular development in PMSG-induced compared with natural follicular growth.

The results of Expt I support the earlier postulation that the effect of diabetes on steroidogenesis either inhibits the conversion of progesterone to testosterone or the aromatization of testosterone to oestradiol (Meurer et al., 1991). The steroid differences occurred in follicles that appeared healthy; however, biochemical indications of decreased steroid production precede macroscopic signs of atresia (Moor et al., 1978; Terranova, 1979). The lowered ratios of oestradiol to progesterone and to testosterone in follicles $\geqslant 7 \mathrm{~mm}$ also indicate that steroidogenesis is most impaired in the largest follicles. Insulin has been demonstrated to affect ovarian transport of glucose (Allen et al., 1981; Otani et al., 1985). However, as diabetes affected progesterone and oestradiol in different ways, increasing the former and decreasing the latter, it is likely that the mechanism involves only certain aspects of steroidogenesis, rather than a general deficiency of energy substrate. The results of Expt 2 confirm the suppressive effect of diabetes on intrafollicular oestradiol.
Although there were no influences of diabetes on ovarian vein concentrations of steroids, peripheral testosterone was increased in diabetic gilts. If the ovary is the source of excess androgen production, as in hyperandrogenic obese women (Friedman and Kim, 1985), increased follicular fluid and ovarian vein concentrations of androgens would be expected, but these were not observed. In ovariectomized pigs, diabetes was also associated with high testosterone concentrations compared with those of non-diabetic gilts $\left(0.06\right.$ versus $0.01 \mathrm{ng} \mathrm{ml}^{-1}$, $\mathrm{SEM}=0.03$; C. A. Carlton and N. M. Cox, unpublished). Those values are similar to the values reported here in ovary-intact gilts and suggest an adrenal origin for the increased testosterone. In ovariectomized streptozotocin-diabetic rats, the adrenals have been implicated as a source of testosterone (Leaming et al., 1982).

In Expt 1, although steroid concentrations were similar in diabetic and non-diabetic gilts except when diameters were $\geqslant 7 \mathrm{~mm}$, IGF-I was significantly lower in all sizes of follicles of diabetic gilts compared with those of non-diabetic gilts. In Expt 2 the small number of large-sized follicles prevents a direct comparison, but IGF-I was low in the follicles available from diabetic gilts. In our previous study (Meurer et al., 1991), IGF-I concentration was low only in the largest follicles of diabetic gilts stimulated with PMSG, again reflecting a possible difference between exogenous and endogenous gonadotrophin support. It has also been demonstrated that PMSG stimulates intrafollicular IGF-I in vivo (Hammond et al., 1988). Insulin and IGF-I share many actions on granulosa cell function, including Downloaded from Bioscientifica.com at 04/26/2023 07:12:02AM 


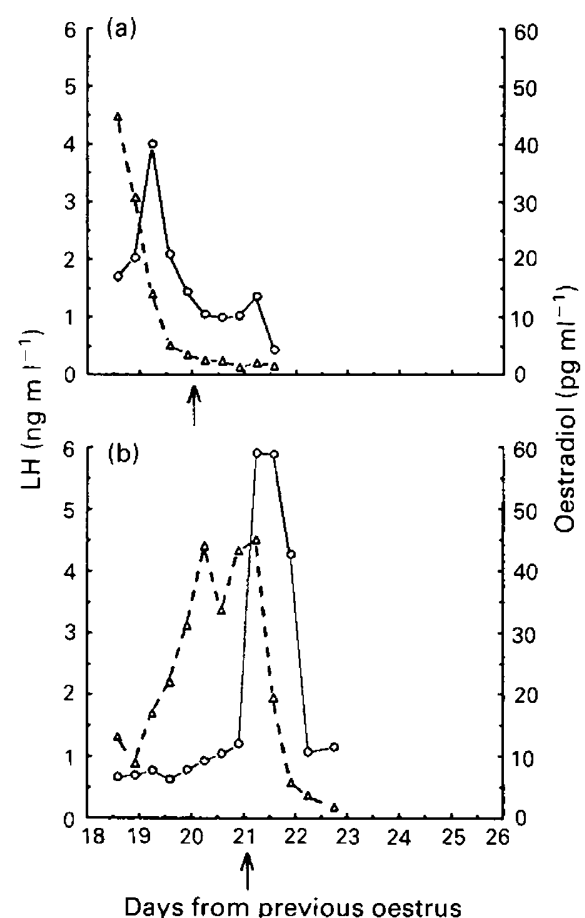

Days from previous oestrus

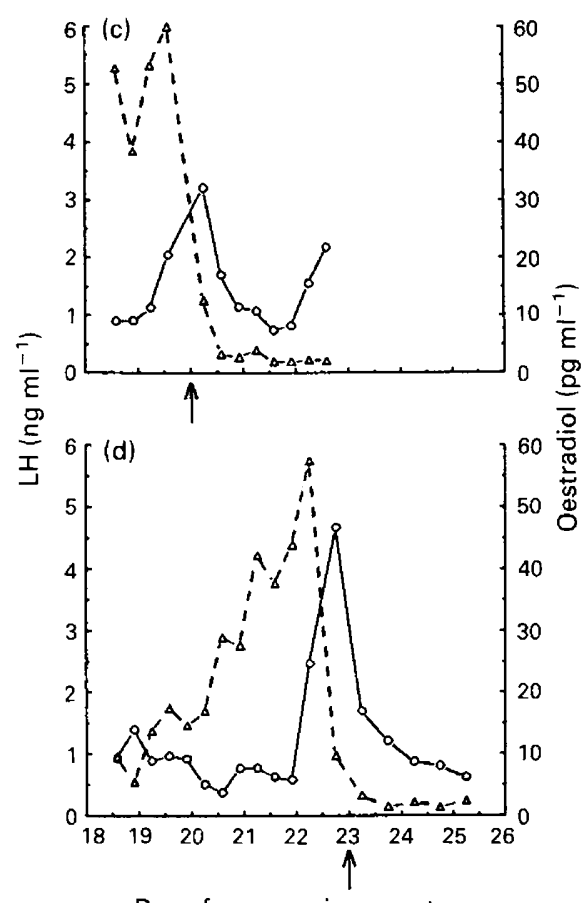

Days from previous oestrus

Fig. 6. Patterns of (-- $\triangle--$ ) oestradiol and (-O-) LH concentrations for four non-diabetic gilts $(a, b, c, d)$. Day of onset of oestrus is marked by arrows.

receptor crossreactivity and possible hybridization of receptors (Adashi et al., 1985; reviewed by Cohick and Clemmons, 1993). However, IGF-I increased FSH-stimulated oestradiol production in vitro, whereas insulin promoted only progesterone secretion (Maruo et al., 1988). It is therefore possible that lower intrafollicular IGF-I concentration rather than absence of insulin accounts for the impairment of oestradiol production by follicles of diabetic gilts.

It must be considered whether diabetes caused decreased follicular production of IGF-I or whether concentrations of IGF-I in follicular fluid reflect those in the general circulation. The similarity of IGF-I concentrations among follicular fluid and venous sources does not support the notion of a significant ovarian contribution to peripheral IGF-I. In addition, in contrast to the work of Spicer et al. (1993) in sheep, IGF-I concentrations were not increased at oestrus in Expt 2. A similarity in peripheral and follicular fluid IGF-I concentrations has been observed in pigs (Hammond et al., 1988) and cattle (Echternkamp et al., 1990). However, it has been demonstrated that granulosa cells produce IGF-I in pigs (Hammond et al., 1985) and rats (Oliver et al., 1989; Hatey et al., 1992). Diabetes mellitus decreased mRNA for IGF-I when examined in nonreproductive tissue from rats (Bornfeldt et al., 1989) and pigs (Leaman et al., 1990), so it is possible that insulin modulates granulosa cell IGF-I synthesis in the same way. Modulation of IGF-I and its binding proteins is associated with gonadotrophin-stimulated follicular development of pigs (Mondschein et al, 1990; Samaras et al., 1992).

The influences of diabetes on intrafollicular production of hormones could not be attributed to differences in ovarian receptors for $\mathrm{LH}$. This result is similar to observations of normal gilts given exogenous insulin, in which there were no influences of exogenous insulin on hCG receptors of granulosa cells (Matamoros et al., 1990).

Although the diabetes did not exert sustained effects on overall concentrations of gonadotrophins, pulsatile LH secretion was increased during the preovulatory period in Expt 1 . These results contrast with those for diabetic rats, in which preovulatory LH concentrations were decreased, ovulation was prevented (Kirchick et al., 1978, 1982; Katayama et al., 1984) and LH pulse frequency was decreased (Dong et al., 1991), and for diabetic humans, in which LH pulse frequency was also reduced (Djursing et al., 1985). The fact that pulsatile secretion of LH was at a higher frequency in diabetic cyclic gilts in the study reported here is even more paradoxical considering that testosterone was increased and negative feedback effects on $\mathrm{LH}$ could be expected, on the basis of studies with male diabetic rats (Chandrakeshar et al., 1991). In addition, loss of body mass comparable to that reported here, but achieved through nutrient restriction, has been shown to decrease LH pulsatility in gilts (Armstrong and Britt, 1987). Thus, the present results could be explained by a decreased sensitivity of the hypothalamus and pituitary of diabetic gilts to negative feedback by peripheral steroids.

It appears, from Expt 2, that sufficient oestradiol was not produced in diabetic gilts to trigger an LH surge. However, LH concentrations did increase during the period from day 18 to day 25 , and the increases appeared to be coordinated, with at least 1 day between the increases. Again these studies contrast with those in rats, in which peripheral oestradiol was not affected by diabetes mellitus lasting for 8 days, but the LH response to $\mathrm{GnRH}$ was impaired (Kirchick et al., 1978, 1979). 

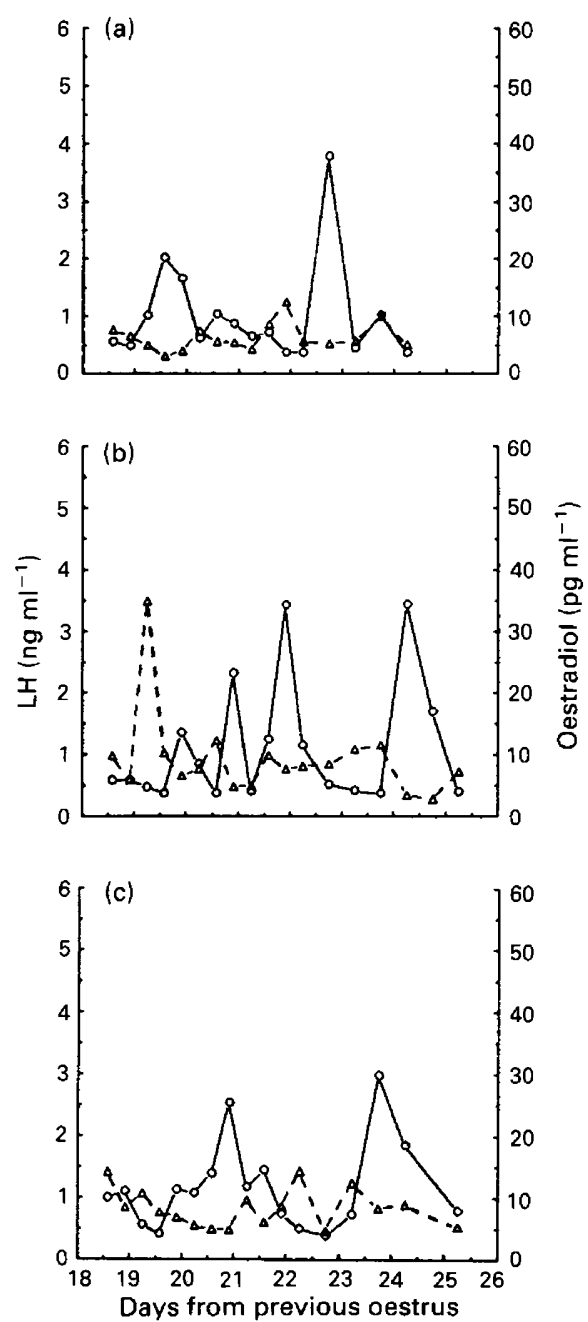

Fig. 7. Patterns of $(--\triangle--)$ oestradiol and $(-\mathrm{O} \rightarrow$ LH concentrations for three diabetic gilts $(a, b, c)$ whose insulin treatment was stopped on day 12. No diabetic gilt exhibited oestrus.

The explanation for these increases is unknown and the sampling schedule did not permit complete characterization of LH patterns. However, the results are consistent with those of Expt 1, which are that acute diabetes, as used in our experimental model, does not impair LH as a prerequisite for decreased follicular development. Rather, the decreased follicular development appears to be the primary event. Studies that demonstrate detrimental effects of diabetes mellitus on $\mathrm{GnRH}$ involve longer durations ( 3 weeks or greater) than the present study, so they are not comparable to the relatively short duration of diabetes mellitus used here (Bestetti et al., 1985, 1989; Valdes et al., 1991).

We conclude that the reduced growth of follicles, abnormalities in follicular steroidogenesis, and failure to ovulate are consequences of the acute onset of diabetes during the period of preovulatory follicular growth and are evident 6 days after removal of insulin treatment. The lack of insulin was associated with lowered IGF-I concentrations in peripheral and intraovarian pathways, and the major consequences were increased incidence of macroscopic atresia and decreased oestradiol production. The acute effects of insulin withdrawal evidenced in the follicle appear to be direct because they were not preceded by negative effects on the hypothalamo-pituitary axis. We therefore conclude that atretic processes increase in ovarian follicles in response to the removal of insulin and that these local changes are probably independent of circulating gonadotrophins.

The authors wish to express sincere appreciation to J. W. Lauderdale (The Upjohn Company) for donating the streptozocin; the National Hormone and Pituitary Program for hCG standard and IGF-I antiserum; N. R. Mason (Eli Lilly Research, Indianapolis, IN) for oestradiol antiserum; G. D. Niswender (Colorado State University) for LH antiserum; L. E. Reichert (Albany Medical College) for supplying purified LH; D.G. Bolt (National Hormone and Pituitary Program, Beltsville, MD) for FSH standards and antiserum and A. B. Moore and I. A. Matamoros for excellent technical assistance. This is paper number J-7647 of the Mississippi Agricultural and Forestry Experiment Station.

\section{References}

Adashi EY, Resnick CE, D'Ercole A, Svoboda ME and Van Wyk JJ (1985) Insulin-like growth factors as intraovarian regulators of granulosa cell growth and function Endocrine Reviews 6 400-420

Allen WR, Nilsen-Hamilton $M$ and Hamilton RT (1981) Insulin and growth factors stimulate rapid post-translational changes in glucose transport in ovarian granulosa cells Journal of Cellular Physiology 108 15-24

Armstrong JD and Britt JH (1987) Nutritionally-induced anestrus in gilts: metabolic and endocrine changes associated with cessation and resumption of estrous cycles Journal of Animal Science 65 508-523

Bestetti GE, Locatelli V, Tirone F, Rossi GL and Muller EE (1985) One month of streptozotocin diabetes induces different neuroendocrine and morphological alterations in the hypothalamo-pituitary axis of male and female rats Endocrinology 117 208-216

Bestetti GE, Boujon CL, Reymond MJ and Rossi GL (1989) Streptozocin diabetes induces functional morphological changes in the mediobasal hypothalamus of male rats: an in vitro study of LHRH release Diabetes 38 471-476

Bornfeldt KE, Arnqvist HJ, Enberg B, Mathews LS and Norstedt G (1989) Regulation of insulin-like growth factor-I and growth hormone receptor gene expression by diabetes and nutritional state in rat tissues Journal of Endocrinology 122 651-656

Carson RS, Findlay JK, Burger HG and Trounson AO (1979) Gonadotropin receptors of the ovine follicle during follicular growth and atresia Biology of Reproduction 21 75-87

Chandrakeshar V, Steger RW, Bartke A, Fadden CT and Kienast SG (1991) Influence of diabetes on the gonadotropin response to the negative feedback effect of testosterone and hypothalamic neurotransmitter turnover in adult male rats Neuroendocrinology 54 30-35

Clark JR, Brazier SG, Wiginton LM, Stevenson GR and Tribble LF (1982) Time of ovarian follicle selection during the porcine estrous cycle Theriogenology 18 697-709

Cohick WS and Clemmons DR (1993) The insulin-like growth factors Annual Review of Physiology 55 131-153

Cox NM, Stuart MJ, Althen TG, Bennett WA and Miller HW (1987) Enhancement of ovulation rate in gilts by increasing dietary energy and administering insulin during follicular growth Journal of Animal Science 64 507-516

Cox NM, Ramirez JL, Matamoros IA, Bennett WA and Britt JH (1988) Influence of season on estrous and luteinizing hormone responses to estradiol benzoate in ovariectomized sows Theriogenology 27 395-405

Dailey RA, Clark JR, First NL, Chapman AB and Casida LE (1975) Effect of short term flushing on follicular development at estrus and ovulation of gilts of different genetic groups Journal of Animal Science 41 842-847

Diekman MA, Green ML and Hunt DA (1990) Effect of vascular cannulation on serum concentrations of $\mathrm{LH}, \mathrm{FSH}$, prolactin and cortisol in prepubertal gilts Theriogenology 34 273-281

Djursing H, Nyholm HC, Hagen C, Carensen G and Pederson LM (1982) Clinical and hormonal characteristics in women with anovulation and insulintreated diabetes mellitus American Journal of Obstetrics and Gynecology 143 876-882

Downloaded from Bioscientifica.com at 04/26/2023 07:12:02AM 
Djursing H, Andersen AN, Hagen C and Petersen K (1985) Gonadotropin secretion before and during acute and chronic dopamine-receptor blockade in insulin-dependent diabetic patients with amenorrhea Fertility and Sterility 44 44-55

Dong Q, Lazurus RM, Wong LS, Vellios M and Handelsman DJ (1991) Pulsatile LH secretion in streptozotocin-induced diabetes in the rat journal of Endocrinology $13149-55$

Echternkamp SE, Spicer LJ, Gregory KE, Canning SF and Hammond JM (1990) Concentrations of insulin-like growth factor-I in blood and ovarian follicular fluid of cattle selected for twins Biology of Reproduction 43 8-14

Flowers B, Martin MJ, Cantley TC and Day BN (1989) The effect of pregnant mares' serum gonadotropin on follicle stimulating hormone and estradiol secretion in the prepubertal gilt Animal Reproduction Science 21 93-100

Foxcroft GR and Hunter MG (1985) Basic physiology of follicular maturation in the pig Journal of Reproduction and Fertility Supplement 33 1-9

Friedman CI and Kim MH (1985) Obesity and its effect on reproductive function Clinical Obstetrics and Gynecology 28 645-663

Goodman RL and Karsch FJ (1980) Pulsatile secretion of luteinizing hormone: differential suppression by ovarian steroids Endocrinology 107 1286-1290

Guthrie HD, Bolt DJ and Cooper BS (1990) Effects of gonadotropin treatment on ovarian follicle growth and granulosa cell aromatase activity in prepubertal gilts Journal of Animal Science 68 3719-3726

Hammond JM, Baranao JLS, Shaleris D, Knight AB, Ramanus JA and Rechler MM (1985) Production of insulin-like growth factors by ovarian granulosa cells Endocrinology 17 2553-2555

Hammond JM, Hsu C, Klindt J, Tsang BK and Downey BR (1988) Gonadotropins increase concentrations of immunoreactive insulin-like growth factor-I in porcine follicular fluid in vivo Biology of Reproduction 38 304-308

Hatey F, Langlois I, Mulsant P, Bonnet A, Benne F and Gasser F (1992) Gonadotropins induce accumulation of insulin-like growth factor $1 \mathrm{mRNA}$ in pig granulosa cells in vitro Molecular and Cellular Endocrinology 86 205-211

Houseknecht KL, Boggs DL, Campion DR, Sartin JL, Kiser TE, Rampacek GB and Amos HE (1988) Effect of dietary energy source and level on serum growth hormone, insulin-like growth factor-I, growth and body composition in beef heifers Journal of Animal Science 66 2907-2915

Howell JL, Breland RT, Wyatt MD, Moore AB and Cox NM (1992) Effect of the lack of insulin in vivo on estradiol production in vitro by ovarian follicles of streptozotocin-diabetic gilts Journal of Animal Science 70 (Supplement 1) 25

Katayama S, Brownsheidle CM, Wootten V, Lee JB and Shimaoka K (1984) Absent or delayed preovulatory luteinizing hormone surge in experimental diabetes mellitus Diabetes 33 324-327

Kirchick HJ, Keyes PL and Frye BE (1978) Etiology of anovulation in the immature alloxan-diabetic rat treated with pregnant mares' serum gonadotropin: absence of the preovulatory luteinizing hormone surge Endocrinology 102 1867-1873

Kirchick HJ, Keyes PL and Frye BE (1979) An explanation for anovulation in immature alloxan-treated diabetic rats treated with pregnant mares' serum gonadotropin: reduced pituitary response to gonadotropin-releasing hormone Endocrinology 105 1343-1349

Kirchick HJ, Keyes PL and Frye BE (1982) Restoration of the LH surge and ovulation by insulin in alloxan-diabetic immature rats treated with pregnant mares' serum gonadotropin Acta Endocrinologica 100 266-273

Leaman DW, Simmen FA, Ramsay TG and White ME (1990) Insulin-like growth factor-I and -II messenger RNA expression in muscle, heart, and liver of streptozotocin-diabetic swine Endocrinology 126 2850-2857

Leaming AB, Mathur RS and Levine JH (1982) Increased plasma testosterone in streptozotocin-diabetic female rats Endocrinology 1329-1333
Maruo T, Hayashi M, Matsuo H, Ueda Y, Morikawa H and Mochizuki M (1988) Comparison of the facilitative roles of insulin and insulin-like growth factor I in the functional differentiation of granulosa cells: in vitro studies with the porcine model Acta Endocrinologica 117 230-240

Matamoros IA, Moore AB and Cox NM (1990) Exogenous insulin and additional dietary energy affect follicular distribution, follicular steroid concentrations and granulosa cell human chorionic gonadotropin binding in swine Biology of Reproduction 33 1287-1295

Matamoros IA, Moore AB and Cox NM (1991) Effects of exogenous insulin and body condition on metabolic hormones and gonadotropin-induced follicular development in prepuberal gilts Journal of Animal Science 69 2081-2091

Meurer KA, Cox NM, Matamoros IA and Tubbs RC (1991) Decreased follicular steroids and insulin-like growth factor-I and increased atresia in diabetic gilts during follicular growth stimulated with PMSG Joumal of Reproduction and Fertility 91 187-196

Mondschein JS, Smith SA and Hammond JM (1990) Production of insulin-like growth factor binding proteins (IGFBPs) by porcine granulosa cells: identification of IGFBP-2 and -3 and regulation by hormones and growth factors Endocrinology 127 2298-2306

Moor RM, Hay MF, Dott HM and Cran DG (1978) Macroscopic identification and steroidogenic function of atretic follicles in sheep Journal of Endocrinology 77 309-318

Niswender GD, Reichert LE and Zimmerman DR (1970) Radioimmunoassay of serum levels of luteinizing hormone throughout the estrous cycle of pigs Endocrinology 87 576-580

Oliver JE, Aitman TJ, Powell JF, Wilson CA and Clayton RN (1989) Insulin-like growth factor I gene expression in the rat ovary is confined to the granulosa cells of developing follicles Endocrinology 124 2671-2679

Otani T, Maruo T, Yukimura N and Mochizuki M (1985) Effect of insulin on porcine granulosa cells: implications of a possible receptor-mediated action Acta Endocrinologica 108 104-110

Rainey MR, Tubbs RC, Cox NM and Bennett LW (1990) Prepubertal exposure to dietary zearalenone alters hypothalamo-hypophysial function but does not impair postpubertal reproductive function of gilts Journal of Animal Science 68 2015-2022

Samaras SE, Hagen DR, Shimasaki S, Ling N and Hammond JM (1992) Expression of insulin-like growth factor-binding protein-2 and -3 messenger ribonucleic acid in the porcine ovary: localization and physiological changes Endocrinology $1302739-2744$

SAS (1988) SAS/STAT User's Guide, SAS Institute Inc, Cary, NC

Spicer LJ, Hanrahan JP, Zavy MT and Enright WJ (1993) Relationship between ovulation rate and concentrations of insulin-like growth factor-I in plasma during the oestrous cycle in various genotypes of sheep Journal of Reproduction and Fertility 97 403-409

Steel RGD and Torrie JH (1980) Principles and Procedures of Statistics McGrawHill Book Co, New York

Terranova PF (1979) Steroidogenesis in experimentally induced atretic follicles of the hamster: a shift from estradiol to progesterone synthesis Endocrinology 108 1885-1890

Tonetta SA and diZerega GS (1989) Intragonadal regulation of follicular maturation Endocrine Reviews 10 205-229

Valdes CT, Elkind-Hirsch KE, Rogers DG and Adelman JP (1991) The hypothalamic-pituitary axis of streptozotocin-induced diabetic female rats is not normalized by estradiol replacement Endocrinology 128 433-440

Wiesak T, Hunter MG and Foxcroft GR (1990) Differences in follicular morphology, steroidogenesis and oocyte maturation in naturally cyclic and PMSG/hCG-treated gilts Journal of Reproduction and Fertility 89 633-641 